\title{
СТВОРЕННЯ ЗДОРОВ'ЯЗБЕРІГАЛЬНОГО ОСВІТНЬОГО СЕРЕДОВИЩА ДЛЯ СТУДЕНТІВ-МЕДИКІВ
}

\author{
Тернопільський національний медичний університет імені І. Я. Горбачевського МОЗ України,
} м. Тернопіль, Україна

\begin{abstract}
Мета: проаналізувати методи організації здоров'язберігального освітнього середовища на кафредрі психіатрії, наркології та медичної психології Тернопільського національного медичного університету імені І. Я. Горбачевського МОЗ України.

Матеріали і методи. У процесі дослідження використовували такі методи: аналіз науково-педагогічної літератури з проблем упровадження здоров'язберігальних технологій в освітній процес, вивчення й узагальнення досвіду підготовки студентів-медиків на кафедрі психіатрії, наркології та медичної психології Тернопільського національного медичного університету імені І. Я. Горбачевського МОЗ України (аналіз лекцій і практичних занять), виявлення організаційно-педагогічних умов створення здоров'язберігального освітнього середовища.

Результати. У статті висвітлено особливості створення здоров'язберігального освітнього середовища для майбутніх лікарів викладачами кафедри психіатрії, наркології та медичної психології Тернопільського національного медичного університету імені І. Я. Горбачевського МОЗ України.

Проведений аналіз різних фрорм і методів освітнього процесу на кафедрі психіатрії, наркології та медичної психології показав, що сприятливим у створенні здоров'язберігального освітнього середовища для студентівмедиків $€$ використання особистісно-орієнтованого підходу, інноваційних методів навчання, психологічного супроводу майбутніх лікарів у навчально-виховному процесі.

Висновки. У сучасних умовах освіта $€$ однією 3 найважливіших сфрер людської діяльності, пов'язаної із підготовкою висококваліфікованих всебічно розвинених та здорових особистостей. Інтенсиффікація навчального процесу призводить до того, що зростає кількість студентів, які можуть адаптуватися до нових вимог із значними зусиллями. Лише створюючи здоров'язберігальне освітнє середовище, впроваджуючи інноваційні підходи (зокрема, особистісно-орієнтований підхід), спрямовані на збереження, зміцнення і фрормування здоров'я учасників навчально-виховного процесу, стає можливим покращити психічне здоров'я майбутніх фахівців.
\end{abstract}

КЛЮЧОВІ СЛОВА: здоров'язберігальне освітнє середовище; особистісно-орієнтований підхід; інноваційні технології; симуляційне навчання.

Останнім часом досить багато уваги приділяють питанню рефрормування медичної галузі, створенню конкурентного середовища між установами, які надають медичні послуги, що є одним із чинників підвищення фрінансової ефективності та якості охорони здоров'я, проте невід'ємним складником успіху форматування української медицини у модель західного взірця є реформування медичної освіти. Важливість якісної підготовки медичних кадрів складно переоцінити і тому необхідною є організація освітнього середовища, яке буде спрямоване на збереження, зміцнення і формування здоров'я всіх учасників навчально-виховного процесу. Від того, яким чином організоване управління педагогічним середовищем, залежить психічний та духовний світ студентів, їхнє бажання самовдосконалюватися та вести здоровий спосіб життя. Позитивний психологічний та емоційний настрій $є$ одним із показників психічного здоров'я майбутніх лікарів. Тому актуальним питанням, яке вимагає вивчення, $€$ організація здоров'язберігального освітнього середовища у підготовці майбутніх лікарів.

Мета роботи: проаналізувати методи організації здоров'язберігального освітнього середовища на кафедрі психіатрії, наркології та медичної психології Тернопільського національного медичного університету імені І. Я. Горбачевського МО3 України.

Матеріали і методи. У процесі дослідження використовували такі методи: аналіз науково-педагогічної літератури з проблем упровадження здоров'язберігальних технологій в освітній процес, вивчення й узагальнення досвіду підготовки студентів-медиків на кафедрі психіатрії, наркології та медичної психології Тернопільського національного медичного університету імені І. Я. Горбачевського МОЗ України (аналіз лекцій і практичних занять), виявлення організаційно-педагогічних 
умов створення здоров'язберігального освітнього середовища.

Результати дослідження та їх обговорення. В організації освітнього середовища поряд із соматичним здоров'ям студентів важливого значення надають збереженню психічного здоров'я майбутніх лікарів.

Негативними фракторами, які фрормують здоров'я студентської молоді у сучасних умовах, $€$ значне психічне навантаження, низький рівень мотивації до навчання, перевтома під час заліково-екзаменаційної сесії. Як наслідок, у студентів може формуватися підвищена особистісна тривожність та емоційна лабільність, незадоволеність власними досягненнями, стосунками в групі тощо.

Аналіз наукової психолого-педагогічної літератури свідчить про те, що є багато наукових праць та публікацій щодо здоров'язберігального освітнього середовища. Зокрема, це наукові роботи О. Антонової, В. Базарного, М. Гриньової, В. Єфрімової, Н. Карапузової та ін.

Питаннями моделювання безпечного для здоров'я освітнього середовища займалися І. Баєва, Д. Іванов, В. Панов, Є. Рибак, С. Сергє$\epsilon в$, В. Слободчиков, А. Тубельський. Формування здоров'я в сучасній освіті студентської молоді здійснюється на основі різних підходів, найважливішими з яких є: гуманістичний (В. Безрукова, І. Бех, Є. Бондаревська, Є. Вайнер, Г. Зайцев, Е. Казін, О. Іонова, Ю. Науменко, О. Савченко, В. Сухомлинський, І. Якиманська та ін.), культурологічний (Г. Апанасенко, В. Бобрицька, Е. Вайнер, С. Волкова, В. Горащук, С. Кириленко, В. Морозова, В. Оржеховська, Л. Попова, О. Савченко, Л. Татарнікова та ін.), компетентнісний (Н. Бібік, Л. Ващенко, О. Локшина, О. Овчарук, О. Пометун, О. Савченко та ін.).

Оскільки навчання й виховання людини здійснюється в певному середовищі, зрозумілим $є$ те, що вплив середовища може як сприяти процесам розвитку індивіда, так і гальмувати ці процеси.

Терміни «освітнє середовище», «середовище навчання», «педагогічне середовище», «здоров'язберігальне середовище» стали широко вживатися не тільки вченими, але й педагогами та психологами-практиками, використовуватися в нормативних документах вищої освіти.

А. Морозова визначає поняття «здоров'язбереження» як якісну характеристику середовища, що показує, наскільки вирішується питання збереження здоров'я суб'єктів освітнього процесу в умовах педагогічного середовища навчального закладу. Тому фрормування здоров'язберігального середовища у навчальному закладі можливе за умови, якщо кожна компонента педагогічного процесу буде виконувати здоров'язберігальну фрункцію [5].
Важливим є підхід Л. Бережної [2], згідно з яким здоров'язберігальне середовище - це середовище, яке комфортне для всіх суб'єктів навчальновиховного процесу, в якому формується цілісне світосприйняття, що є передумовою гармонійно розвиненої особистості.

Отже, важливими складовими здоров'язберігального середовища є чинники, що впливають на здоров'я і здоровий спосіб життя; уміння відстежувати позитивні й негативні зміни в стані власного здоров'я і здоров'я оточуючих; уміння створювати середовище, сприятливе для здоров'я; володіння ефективними оздоровчими технологіями.

На нашу думку, процес фрормування свідомого ставлення до власного психічного здоров'я передбачає поєднання інформаційного й мотиваційного компонентів із практичною діяльністю студентів.

Для розвитку мотивації досягнення для майбутніх лікарів на кафредрі психіатрії, наркології та медичної психології створюється розвиваюче освітнє середовище з використанням інноваційних методів навчання, які сприяють усвідомленню студентами важливості знань і практичних навичок для успішного оволодіння ними майбутньою професійною діяльністю, розвитку клінічного мислення [6].

Заслуговує на увагу застосування такого інноваційного методу, як симуляційне навчання, яке також є одним із чинників ефрективної мотивації досягнення успіху студентів-медиків в оволодінні майбутнім фахом.

Центр симуляційного навчання сприяє засвоєнню знань та відпрацюванню різних клінічних навичок майбутніх лікарів завдяки використанню манекенів-симуляторів, тренажерів і стандартизованих пацієнтів. Симуляційні методи навчання дозволяють майбутньому лікарю здобувати клінічний досвід без ризику для пацієнта, не обмежувати кількість повторів при відпрацюванні практичної навички, реалізувати професійні навички і вміння відповідно до встановленого щодо даних умов алгоритму.

Беручи до уваги той фракт, що здоров'я здебільшого залежить від самої людини, її свідомості, викладачі кафедри психіатрії, наркології та медичної психології приділяють значну увагу формуванню в студентів-медиків позитивного ставлення до власного здоров'я. Основою такої діяльності є певна система взаємодії педагогів та студентів, яка включає створення сприятливого психологічного клімату на практичних заняттях та лекціях, навчання вмінню керувати власними емоціями, почуттями [3], щоб запобігти емоційному вигоранню, навчання підтримання впевненості у власних можливостях, організацію просвітницької роботи, до якої залучають і фрахівців Центру психологічного консультування. 
В. Панок та В. Острова у власних дослідженнях наголошують на тому, що в юнацькому віці людина найбільшою мірою потребує психологічної допомоги та підтримки. Науковці звертають увагу на те, що кардинальні зміни в розвиткові особистості зумовлюють значну кількість психологічних проблем: проблеми адаптації, профресійного становлення, міжособистісного спілкування, сімейні проблеми [8].

С. В. Бобрук відзначає важливість роботи зі студентами спеціаліста в галузі психології, який, у свою чергу, зможе вчасно виявити та надати допомогу тим, хто входить у групу ризику щодо психоемоційних розладів.

Таким чином, пріоритетними завданнями Центру психологічного консультування $є$ : збереження психічного здоров'я студентів у процесі навчальної діяльності; психологічна діагностика, психологічне консультування, психологічна просвіта батьків; просвітницько-профрілактична діяльність серед викладачів та студентів.

Ми вважаємо, що продуктивною в плані організації здоров'язберігального освітнього середовища $є$ також реалізація особистісно-орієнтованого підходу в навчально-виховному процесі, який орієнтується на повагу до унікальності та гідності особистості, розвиток та саморозвиток її природних задатків та здібностей, створення атмосорери захищеності та підтримки [7].

У безпосередньому спілкуванні педагога зі студентом здійснюється найголовніше в педагогічній діяльності - вплив особистості на особистість. Ефективне педагогічне спілкування, на нашу думку, має поєднувати відкритість, дотримання педагогічного такту; встановлення особистісного контакту, щоб кожен студент відчував зверненість саме до нього; створення ситуацій успіху через схвалення потенційних можливостей студентів.

Особливістю педагогічного спілкування під час проведення практичних занять $€$ індивідуальний підхід до студентів із метою розкриття їх внутрішнього потенціалу. Важливу роль у процесі цієї діяльності відіграє інтелектуальна активність студентів, яка $€$ проявом зацікавленості студентів-медиків навчально-виховним процесом.

Створення певних взаємин між учасниками педагогічного процесу пов'язано з позитивним ставленням до особистості іншої людини, визнанням її цінності без упереджень, зайвої критичності та схильності до оцінювання, що сприяє кращій реалізації творчого потенціалу кожного студента та підтримці його психічного здоров'я.

Серед засобів, що сприяють успішній реалізації особистісно-орієнтованого підходу, усе більшого визнання набувають інтерактивні групові методи навчання.
Інтерактивні методи навчання дозволяють стимулювати навчальну активність студентів при вивченні психологічних дисциплін, сприяють гуманізації навчання, самоствердженню особистості. Пропоновані нами вправи і елементи соціально-психологічного тренінгу дають студентам можливість ґрунтовніше працювати над фрормою висловлення власних ідей, дозволяють долати певні стереотипи, відпрацьовувати вміння презентувати себе і розуміти власні емоції, вміння ефрективно взаємодіяти у мікрогрупах, здатність до самопізнання.

Серед студентів Тернопільського національного медичного університету імені І. Я. Горбачевського МО3 України багато іноземних громадян. При навчанні іноземних студентів викладач повинен будувати педагогічне спілкування, враховуючи ряд чинників: міжкультуральний характер спілкування, спілкування викладача зі студентами-іноземцями перших курсів тісно пов'язане з їх адаптацією. Науковцями виділено такі комунікативні вміння викладачів: вміння вступати в контакт, керувати власними емоціями, особливо при вирішенні конфліктів, вміння створити сприятливу емоційну атмосферу в аудиторії, вміння впливати на іноземних студентів із врахуванням їх національної приналежності, вміння зрозуміти мотиви поведінки іноземних студентів при спілкуванні з викладачем.

Адже, покращення мотивації майбутніх лікарів $€$ запорукою їх подальшого ефективного особистісного та профресійного становлення.

Активна навчально-пізнавальна діяльність забезпечує не тільки розширення знань, умінь і навичок, а є умовою фрормування особистості та розвитку її цілісної мотиваційної сорери [1].

Зокрема, під час занять з інтернами-психіатрами викладачі кафедри передають їм знання про організацію психіатричної допомоги, яку мали можливість спостерігати в швейцарській клініці. Більшість аспектів набутого досвіду впроваджується в роботу Комунального некомерційного підприємства «Тернопільська обласна клінічна психоневрологічна лікарня» Тернопільської обласної ради [4].

Важливою умовою перебування пацієнта в стаціонарі на сьогодні $€$ те, що процес лікування не обмежується лише прийманням медикаментів, а більшою мірою постійною роботою з ним у плані відновлення соціальної активності, набуття або відновлення навичок самостійного життя, психотерапії у різних її видах.

У рамках такої діяльності лікарі-інтерни здобувають безцінний досвід психологічної реабілітації психічно хворих, що неодмінно допоможе їм в їх майбутній практиці. Так, лікарі-інтерни розробляють програми реабілітації та допомагають пацієнтам вчитися доглядати за собою, готувати їжу, 
їх заохочують до читання, малювання чи інших видів активності. Робота стаціонару спланована таким чином, щоб максимально з моменту пробудження і до вечора пацієнт був задіяний у різноманітних видах активності, які можуть різнитися між собою залежно від діагнозу пацієнта. Будучи залученими в цей процес, інтерни під контролем викладача самостійно визначають і обирають види діяльності, які необхідні пацієнту, проводять з ними відповідну роботу.

Набір цих активностей підбирають індивідуально для пацієнта і покликаний забезпечити якнайкращий результат у плані відновлення якості життя саме для нього.

Очевидно, що для забезпечення такого великого об'єму комплексного лікування необхідні зусилля цілої команди спеціалістів, саме тому участь лікарів-інтернів $є$ досить важливою. Так, у процесі лікування одного пацієнта бере участь мультидисциплінарна бригада: лікуючий лікар, який відповідає за призначення фрармакологічних засобів та контроль медичного стану пацієнта, спеціаліст із догляду, який відповідає за розпорядок дня пацієнта, займає його різними видами роботи, та команда психотерапевтів та психологів, які проводять як індивідуальні, так і групові заняття, арт-терапію, займаються психоосвітньою роботою тощо. У процесі роботи інтерни мають змогу оволодіти і цими навичками, що є надзвичайно важливо, адже в майбутньому вони зможуть демонструвати ці вміння в своїй повсякденній праці вже на робочому місці.

Робота в команді передбачає постійне обговорення стану пацієнта, тісну комунікацію між членами мультидисциплінарної бригади, спільне вирішення тактики лікування, турботу про стан здоров'я, що є пріоритетним завданням сучасної психіатрії.

\section{Висновки}

У сучасних умовах освіта $€$ однією 3 найважливіших сфер людської діяльності, пов'язаної із підготовкою висококваліфікованих всебічно розвинених особистостей. Особистісний розвиток студента і формування його готовності до майбутньої професійної діяльності $€$ основними при удосконаленні роботи вищого навчального закладу освіти, в тому числі й медичної, на сучасному етапі розвитку суспільства. Інтенсисрікація навчального процесу призводить до того, що зростає кількість студентів, які можуть адаптуватися до нових вимог із значними зусиллями. Лише створюючи здоров'язберігальне освітнє середовище, впроваджуючи інноваційні підходи (зокрема, особистісно-орієнтований підхід), спрямовані на збереження, зміцнення і фрормування здоров'я учасників навчально-виховного процесу, стає можливим покращити психічне здоров'я майбутніх фрахівців.

Проведений нами аналіз різних срорм і методів освітнього процесу на кафредрі психіатрії, наркології та медичної психології показав, що сприятливим у створенні здоров'язберігального освітнього середовища для студентів-медиків $€$ використання особистісно-орієнтованого підходу, інноваційних методів навчання, психологічного супроводу майбутніх лікарів у навчально-виховному процесі в університеті.

Перспективи подальших досліджень полягають у визначенні найефективніших методів збереження і зміцнення психічного здоров'я студентів.

\section{Список літератури}

1. Активні форми навчання як спосіб мотивації лікарів-інтернів / І. Л. Височина, В. В. Крамарчук, О. А. Росицька, С. Ф. Агарков // Актуальні проблеми розвитку освіти і науки в умовах глобалізації : матеріали Всеукраїнської наукової конореренції. - 2016. - Т. 2 (ч. 1). - С. 227.

2. Бережна Л. К. Програмно-цільовий підхід до організації роботи школи сприяння здоров'ю / Л. К. Бережна // Управління школою (Основа). - 2011. - № 19. - С. 63-66.

3. Бобрук С. В. Шляхи покращення навчання з метою попередження психоемоційних порушень у студентів-медиків вищих медичних закладів / С. В. Бобрук // Медична освіта. - 2018. - № 1. - C. 8-10. https://doi.org/10.11603/me.24145998.2018.1.8679.

4. Лукащук Л. Швейцарська модель охорони психічного здоров'я - в Україні / Л. Лукащук // Всеукраїнська медична газета «Ваше здоров'я». - 2018. - № 51-52. - С. 22-23. https://issuu.com/vzkievua/docs/vz_51-52_2018.

5. Морозова А. А. Здоровьесберегающая среда образовательного учреждения / А. А. Морозова // Научные исследования в образовании. - 2008. - № 2. - С. 45-46.

6. Мотивація досягнення як важливий чинник успішного професійного становлення студентів-медиків / О. П. Венгер, Т. П. Гусєва, Ю. І. Мисула та ін. // Медична освіта. - 2018. - № 4. - С. 31-36.

7. Особистісно-орієнтований підхід при викладанні психологічних дисциплін для студентів медичних спеціальностей за кредитно-модульною системою навчання / С. І. Шкробот, О. П. Венгер, Т. П. Гусєва та ін. // Медична освіта. 2012. - № 3 (додаток). - С. 208-210.

8. Психологічна служба : підручник / [В. Г. Панок (наук. ред.), А. Г. Обухівська, В. Д. Острова та ін.]. - К. : Ніка-Центр, 2016. -362 c. 


\section{References}

1. Vysochyna I.L., Kramarchuk V.V., Rosytska O.A., \& Aharkov S.F. (2016). Aktyvni formy navchannia yak sposib motyvatsii likariv-interniv [Active forms of teaching as a way of motivating interns]. Aktualni problemy rozvytku osvity i nauky $v$ umovakh hlobalizatsii. Materialy vseukrainskoi naukovoi konferentsii - Actual Problems of Development of Education and Science in the Conditions of Globalization. Proceedings of the All-Ukrainian Scientific Conference, 1 (2), 227 [in Ukrainian].

2. Berezhna, L.K. (2011). Prohramno-tsilovyi pidkhid do orhanizatsii roboty shkoly spryiannia zdoroviu [A program-based approach to organizing a health promotion school]. Upravlinnia shkoloiu (Osnova) - School Management (Basics), 19, 63-66.

3. Bobruk, S.V. (2018) Shliakhy pokrashchennia navchannia z metoiu poperedzhennia psykhoemotsiinykh porushen u studentiv-medykiv vyshchykh medychnykh zakladiv [Ways of improving education with the aim of prevention of psychoemotional violations in medical students of higher medical institutions]. Medychna osvita - Medical Education, 1, 8-10. Retrieved from: https://doi.org/10.11603/me.2414-5998.2018.1.8679 [in Ukrainian].

4. Lukashchuk, L. Shveitsarska model okhorony psykhichnoho zdorovia - v Ukraini [The Swiss model of mental health to Ukraine]. Vseukrainska medychna hazeta «Vashe zdorovia» - All-Ukrainian Medical Newspaper "Your Health", 51-52, 22-23. Retrieved from: https://issuu.com/vzkievua/docs/vz_51-52_2018 [in Ukrainian].

5. Morozova, A.A. (2008). Zdorovye sberegayushchaya sreda obrazovatelnogo uchrezhdeniya [Health-saving environment of an educational institution]. Nauchnyye issledovaniya $v$ obrazovanii - Scientific Research in Education, 2, 45-46 [in Russian].

6. Venher, O., Husieva, T., Mysula, Y., Sas, L., Smashna, O., Bilous, V., Liuta O., \& Nestorovysch, Y. (2018). Motyvatsiia dosiahnennia yak vazhlyvyi chynnyk uspishnoho profesiinoho stanovlennia studentiv-medykiv [Motivation of achievement as an important factor of successful professional development of medical students]. Medychna osvita - Medical Education 4, 31-35 Retrieved from: https://doi.org/10.11603/me.2414-5998.2018.4.9388 [in Ukrainian].

7. Shkrobot, S.I., Venher, O.P., Husieva, T.P., Mysula, Yu.I., Nestorovych, Ya.M., Sas, L.M., \& Bilous, V.S. (2012). Osobystisno-oriientovanyi pidkhid pry vykladanni psykholohichnykh dystsyplin dlia studentiv medychnykh spetsialnostei za kredytno-modulnoiu systemoiu navchannia [Person-oriented approach in teaching psychological disciplines for medical specialties students in the credit-modular system of education]. Medychna osvita - Medical Education, 3(add.), 208-210 [in Ukrainian].

8. Obukhivska, A.H., \& Ostrova, V.D. (2016). Psykholohichna sluzhba [Psychological service]. Panok, V.H. (Ed.). Kyiv: Nika-Tsentr [in Ukrainian].

\section{СОЗДАНИЕ ЗДОРОВЬЕСОХРАНЯЮЩЕЙ ОБРАЗОВАТЕЛЬНОЙ СРЕДЫ ДЛЯ СТУДЕНТОВ- МЕДИКОВ}

Е. П. Венгер, Т. П. Гусева, Ю. И. Мысула, Л. М. Сас, Е. Е. Смашна, В. С. Билоус, О. А. Люта

Тернопольский национальный медицинский университет имени И. Я. Горбачевского МЗ Украины,

г. Тернополь, Украина

Цель: проанализировать (выявить особенности) методы организации здоровьесохраняющей образовательной среды на кафедре психиатрии, наркологии и медицинской психологии Тернопольского национального медицинского университета имени И. Я. Горбачевского МЗ Украины.

Материалы и методы. В процессе исследования использовали следующие методы: анализ научно-педагогической литературы по проблемам внедрения здоровьесохраняющих технологий в образовательный процесс, изучение и обобщение опыта подготовки студентов-медиков на кафедре психиатрии, наркологии и медицинской психологии Тернопольского национального медицинского университета имени И. Я. Горбачевского МЗ Украины (анализ лекций и практических занятий), выявление организационно-педагогических условий создания здоровьесохраняющей образовательной среды.

Результаты. В статье освещены особенности создания здоровьесохраняющей образовательной среды для будущих врачей преподавателями кафедры психиатрии, наркологии и медицинской психологии Тернопольского национального медицинского университета имени И. Я. Горбачевского МЗ Украины.

Проведенный анализ различных форм и методов образовательной работы на кафедре психиатрии, наркологии и медицинской психологии показал, что благоприятным в создании здоровьесохраняющей образовательной среды для студентов-медиков является использование личностно-ориентированного подхода, инновационных методов обучения, психологического сопровождения будущих врачей в учебновоспитательном процессе.

Выводы. В современных условиях образование является одной из важнейших сорер человеческой деятельности, связанной с подготовкой высококвалифицированных всесторонне развитых и здоровых личностей. Интенсификация учебного процесса приводит к тому, что растет количество студентов, которые могут адаптироваться к новым требованиям со значительными усилиями. Только создавая здоровьесохраняющую образовательную среду, внедряя инновационные подходы (в частности, личностноориентированный подход), направленные на сохранение, укрепление и формирование здоровья участников учебно-воспитательного процесса, становится возможным улучшить психическое здоровье будущих специалистов-врачей.

КЛЮЧЕВЫЕ СЛОВА: здоровьесохраняющая образовательная среда; личностно-ориентированный подход; инновационные технологии; симуляционное обучение. 
CREATION OF A HEALTHY SAVING EDUCATIONAL ENVIRONMENT FOR MEDICAL STUDENTS

O. P. Venger, T. P. Gusyeva, Yu. I. Mysula, L. M. Sas, O. Ye. Smashna, V. S. Bilous, O. O. Lyuta

I. Horbachevsky Ternopil National Medical University, Ternopil, Ukraine

Purpose: to analyze methods of organizing a health education environment at the Department of Psychiatry, Narcology and Medical Psychology of I. Horbachevsky Ternopil National Medical University.

Materials and Methods. The following methods were used in the research: analysis of scientific and pedagogical literature of the problems of implementation of health-saving technologies in the educational process, study and generalization of the experience of medical students training at the Department of Psychiatry, Narcology and Medical Psychology of I. Horbachevsky Ternopil National Medical University (analysis of lectures and practical classes), identifying organizational and pedagogical conditions for creating a healthy educational environment.

Results. The article highlights the features of creating a health education environment for future doctors by teachers of the Department of Psychiatry, Narcology and Medical Psychology of I. Horbachevsky Ternopil National Medical University.

The conducted analysis of different forms and methods of educational process at the Department of Psychiatry, Narcology and Medical Psychology showed that the use of a personal-oriented approach, innovative teaching methods, psychological support of future doctors in teaching is beneficial in creating health-saving educational environment for medical students process.

Conclusions. In today's context, education is one of the most important spheres of human activity associated with the training of highly qualified, well-developed and healthy personalities. The intensification of the educational process leads to an increase in the number of students who can adapt to the new requirements with considerable effort. Only by creating a health-friendly educational environment, by introducing innovative approaches (in particular, a person-centered approach) aimed at preserving, enhancing and shaping the health of participants in the educational process, will be possible to improve the mental health of future professionals.

KEY WORDS: health-saving educational environment; personality-oriented; approach; innovative technologies.

Рукопис надійшов до редакції 10.09.2019 p.

\section{Відомості про авторів:}

Венгер Олена Петрівна - доктор медичних наук, професор, завідувач кафедри психіатрії, наркології та медичної психології Тернопільського національного медичного університету імені І. Я. Горбачевського МОЗ України; тел.: +38(0352) 43-57-71.

Гусєва Тетяна Павлівна - кандидат психологічних наук, асистент кафредри психіатрії, наркології та медичної психології Тернопільського національного медичного університету імені І. Я. Горбачевського МОЗ України; тел.: +38(0352) 43-57-71.

Мисула Юрій Ігорович - кандидат медичних наук, доцент кафедри психіатрії, наркології та медичної психології Тернопільського національного медичного університету імені І. Я. Горбачевського МОЗ України; тел.: +38(0352) 43-57-71.

Сас Леся Михайлівна - кандидат медичних наук, доцент кафедри психіатрії, наркології та медичної психології Тернопільського національного медичного університету імені І. Я. Горбачевського МОЗ України; тел.: +38(0352) 43-57-71.

Смашна Олена Євгенівна - кандидат медичних наук, доцент кафедри психіатрії, наркології та медичної психології Тернопільського національного медичного університету імені І. Я. Горбачевського МОЗ України; тел.: +38(0352) 43-57-71.

Білоус Володимир Сергійович - кандидат медичних наук, асистент кафедри психіатрії, наркології та медичної психології Тернопільського національного медичного університету імені І. Я. Горбачевського МОЗ України; тел.: +38(0352) 43-57-71.

Люта Ольга Олександрівна - кандидат медичних наук, асистент кафредри психіатрії, наркології та медичної психології Тернопільського національного медичного університету імені І. Я. Горбачевського МОЗ України; тел.: +38(0352) 43-57-71. 